JAMP: Jurnal Adminitrasi dan Manajemen Pendidikan

Volume 1 Nomor 2 Juni 2018, Hal : 213-221

Tersedia Online di http://journal2.um.ac.id/index.php/jamp/

ISSN 2615-8574 (online)

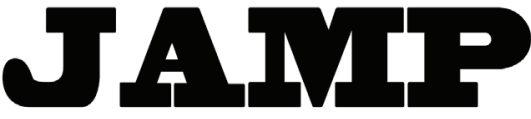

JURNAL ADMINISTRASI DAN MANAJEMEN PENDIDIKAN

\title{
PELAKSANAAN SUPERVISI MANAJERIAL DALAM RANGKA IMPLEMENTASI MANAJEMEN BERBASIS SEKOLAH
}

\author{
Dhiyana Nur Auliya Sari \\ Ibrahim Bafadal \\ Bambang Budi Wiyono \\ dhiyananurliya69@gmail.com \\ Universitas Negeri Malang, Jl. Semarang No. 5 Malang 65145
}

\begin{abstract}
The qualitative study aimed at described as managerial target as a administration schools that serves as a supporter of learning, and asked the education to be relevant. Target managerial supervision includes two kinds of the principal as manager education, and the 8 national education standards in school. By function it known that the role of a superintendent as managerial supervisor is as a consultant, managing, fostering, and accompanies in dealing with common problems on managerial governance in school. School supervisor consultation and assistance to the school when any monitoring activities managerial school. Based on this research, writer expect related stakeholders of them the school principal the period next and the school committee in the development of Junior High Schools 1 Kanigoro as a school of the model inducing schools in areas Kanigoro and surrounding areas.
\end{abstract}

Keywords: managerial supervision, controlling, implementation, school-based management

\begin{abstract}
Abstrak: Penelitian kualitatif yang bertujuan mendeskripsikan sasaran supervisi manajerial sebagai langkah pengelolaan administrasi sekolah yang berfungsi sebagai pendukung terlaksananya pembelajaran, dan bertujuan agar terciptanya pendidikan yang relevan. Sasaran supervisi manajerial meliputi dua macam yakni Kepala Sekolah selaku manager pendidikan, dan Pencapaian 8 Standar Nasional Pendidikan di sekolah. Hal ini berfungsi dalam mendukung efisiensi dan keefektifan supervisi manajerial maka diketahui bahwasanya peran pengawas adalah sebagai konsultan, pengarah, membina, dan mendampingi dalam menangani permasalahan umum mengenai tata kelola manajerial yang ada di sekolah. Pengawas melakukan pendampingan kepada pihak sekolah ketika ada kegiatan pemantauan manajerial sekolah. Berdasarkan penelitian ini, penulis mengharapkan pihak-pihak yang terkait diantaranya kepala sekolah periode selanjutnya dan komite sekolah dalam perkembangan SMP Negeri 1 Kanigoro sebagai sekolah model yang mengimbas sekolahsekolah lain di wilayah Kanigoro dan sekitarnya.
\end{abstract}

Kata kunci: supervisi manajerial, pengawasan, implementasi, manajemen berbasis sekolah

Penyelenggaraan program pendidikan di sebuah sekolah tidak akan terlepas dari konsep manajemen pendidikan, karena manajemen pendidikan dapat diartikan sebagai segala hal yang berkaitan dengan pengelolaan proses pendidikan untuk mencapai tujuan yang telah ditetapkan, baik tujuan jangka pendek, menengah, maupun tujuan jangka panjang. Pemerintah sejak tahun 1999 membuat terobosan dengan menerapkan program pelaksanaan Manajemen Berbasis Sekolah (MBS) di seluruh sekolah. Manajemen Berbasis Sekolah menurut merupakan paradigma baru yang memberikan otonomi luas pada tingkat sekolah (pelibatan masyarakat) dalam kerangka kebijakan pendidikan nasional. Sekolah dituntut secara mandiri menggali, mengalokasikan, menentukan prioritas, mengendalikan, dan mempertanggungjawabkan pemberdayaan sumber-sumber, baik kepada masyarakat maupun pemerintah. MBS yang pada prinsipnya memerlukankerjasama berbagai pihak secara bertahap, dengan prinsip ekuifinalitas, desentralisasi, pengelolaan mandiri, dan inisiatif manusia. Masing-masing 
stakeholder atau pemangku kepentingan pendidikan memiliki peran khusus untuk melaksanakan program pendidikan dan tata pengelolaan manajemen pendidikan, diantaranya adalah dinas pendidikan, kepala sekolah, komite sekolah, dan guru. Dinas pendidikan berperan dalam mengeluarkan petunjuk teknis dan monitoring pelaksanaan program serta menyediakan bantuan teknis ke sekolah-sekolah jika diperlukan, sedangkan kepala sekolah, guru, dan komite sekolah sebagai pelaksana internal berperan dalam melaksanakan program sesuai prinsip-prinsip di atas, di samping itu komite sekolah berperan dalam pengawasan pelaksanaan program sekolah dan memberi masukan kepadakepala sekolah. Desentralisasi pendidikan tersebutlah yang membuat keputusan dibidang pengelolaan sekolah di buat oleh kepala sekolah dengan pendampingan dan pengarahan dari pengawas dinas kabupaten/kota, sebab mutu pendidikan yang maksimal perlu upaya pembaharuan dan memperhatikan semua komponen yang ada di dalamnya. Salah satu keberhasilan pendidikan ditentukan oleh komponen supervisi yang ada di sebuah sekolah. Oleh karena itu, pemerintah mengadakan supervisi terhadap pelaksanaan pendidikan. Menurut Satori (2016: 38) "supervisi merupakan kegiatan pengawasan dengan fokus utama melakukan penilaian keterlaksanaan kaidah-kaidah keilmuan dalam bentuk konsep dan teori yang melandasi pekerjaan profesional". Supervisi dilakukan dalam hubungan profesional antara pengawas dan orangorang yang melaksanakan pekerjaan profesional, dalam penyelenggaraan sekolah hubungan profesional yang dimaksudkan misalnya antara pengawas dan guru. Supervisi memiliki esensi mendorong kepatuhan profesional, yaitu pelaksanaan pekerjaan yang didasarkan atas konsep, teori, dan refleksi praktik yang benar.

Adapun kelebihan dan kaitannya dengan penelitian ini adalah SMP Negeri 1 Kanigoro Blitar telah menerapkan Manajemen Berbasis Sekolah dan memenuhi aspek supervisi manajerial delapan standar, yaitu: a) sekolah ini menjadi salah satu sekolah di pusat pemerintahan Kabupaten Blitar yang melibatkan peran pengawas dari Dinas Pendidikan Kabupaten Blitar untuk menumbuhkan partisipasi warga sekolah dalam lingkup Implementasi Manajemen Berbasis Sekolah; b) jalinan kerjasama teamwork pendidik dan tenaga kependidikan SMPN 1 Kanigoro sangat bagus, kerjasama ini terjalin antara kepala sekolah, staf karyawan, guru, komite, wali murid, dan pengawas dinas pendidikan sehingga sekolah dapat meraih capaian delapan standar pendidikan dan menerapkan prinsip-prinsip MBS; c) Supervisi manajerial yang ada di sekolah ini dilakukan tim pengawas secara konsisten minimal satu bulan sekali. Supervisi yang dilakukan pun juga jauh dari kesan penilaian yang terkesan kaku dan menakutkan, akan tetapi justru sebaliknya. Paradigma yang sejak dulu terbentuk pun juga berubah seiring berjalannya waktu, supervisi manajerial berupa pembinaan dan pendampingan. Adanya pengimplementasian Manajemen Berbasis Sekolah di SMPN 1 Kanigoro tentunya tidak luput dari peran masing-masing warga sekolah baik itu kepala sekolah, wakil kepala sekolah (bidang kurikulum, kesiswaan, dan sarpras), guru, siswa, staf tata usaha, tenaga kependidikan, komite sekolah dan juga pengawas sekolah yang melakukan kegiatan monitoring, dan supervisi. Oleh karena supervisi manajerial yang ada dalam sekolah ini ditekankan pada pendampingan, pembinaan, pemantauan dan penilaian kemampuan kinerja kepala sekolah, guru dan staf dalam melaksanakan tugas. Peran pengawas sebagai konsultan manajerial sekolah harus dapat dioptimalisasi guna melaksanakan hal utama dalam konteks otonomidaerah sekarang ini, yaitu Manajemen Berbasis Sekolah (MBS) sesuai dengan prinisip yang terfokus pada mutu, bottom-up planning and desicion making, manajemen yang transparan, pemberdayaan masyarakat, dan peningkatan mutu secara berkelanjutan.

\section{METODE}

Penelitian ini menggunakan metode kualitatif studi kasus tunggal. Alasan peneliti menggunakan metode penelitian ini pertama adalah untuk memaparkan hasil penelitian secara prosedural mengenai pelaksanaan kegiatan supervisi manajerial di sekolah yang memiliki kurikulum lingkungan hidup, yaitu SMP Negeri 1 Kanigoro Blitar yang telah sukses mengelola 7 substansi manajemen pendidikan dan menerapkan Manajemen Berbasis Sekolah sejak tahun 2005. Kedua, karena peneliti ingin mengetahui dan menjelaskan secara rinci mengenai peranpelaksanaan supervisi manajerial dalam pengimplementasian MBS di sebuah sekolah yang lokasinya menjadi tempat pergeseran pemerintahan Kabupaten Blitar. 
Berdasarkan fokus penelitiannya, peneliti memanfaatkan penelitian kualitatif dengan rancangan studi kasus di SMPN 1 Kanigoro Blitar.

Informan yang dipilih oleh peneliti yakni:(1) Kepala SMP Negeri 1 Kanigoro; (2) Wakil Kepala bidang Kurikulum; (3)Wakil Kepala Bidang Sarana Prasarana;(4) Kepala Tenaga Administrasi SMP Negeri 1 Kanigoro;dan (5) Pengawas Manajerial Dinas Pendidikan Kabupaten Blitaryang khusus membina dan mengawasi SMPN 1 Kanigoro. Kriteria peneliti dalam memilih informan tersebut dilihat dari peran, pengalaman, dan masa jabatan yang tergolong senior sehingga dapat memaparkan informasi dengan jelas sesuai kenyataan dan realitasnya dengan topik dan kajian informasi. Penelitian ini menggunakan teknik-teknik dalam rangka pengumpulan data di lapangan diantaranya: (1) teknik observasi berupa pengamatan dan pencatatan secara sistematik terhadap gejala yang tampak pada objek penelitian. Observasi yang dilakukan peneliti dengan mengamati prosedur pembinaan, pendampingan dan penilaian mengenai sekolah MBS di SMPN 1 Kanigoro; (2) teknik wawancara, merupakan teknik percakapan yang dilakukan oleh kedua belah pihak melibatkan peneliti sebagai pewawancara (interviewer) dan subyek atau responden sebagai terwawancara (interviewee). Wawancara yang digunakan peneliti adalah wawancara semi terstruktur, peneliti tetap menggunakan pedoman atau instrumen wawancara yang telah dibuat, namun tidak menutup kemungkinan peneliti dapat menanyakan semua hal yang tersirat dari penjelasan informan secara spontan yang tidak terdapat dalam pedoman wawancara; (3) Studi dokumentasi, dikumpulkan setelah peneliti melakukan pengamatan data dan setelah melakukan wawancara kepada informan-informan terkait dengan supervisi manajerial dan implementasi MBS di sekolah. Hasil dari dokumentasi akan dijadikan sebagai bukti dari hasil wawancara maupun hasil observasi, sehingga data yang diperoleh terjamin kebenarannya.

\section{HASIL}

\section{Sasaran Supervisi Manajerial dalam rangka implementasi MBS di SMP Negeri 1 Kanigoro}

Sasaran supervisi manajerial merupakan hasil yang diharapkan dari suatu pelaksanaan manajerial sekolah mencakup aspek administratif sekolah. Pengawas memiliki sasaran supervisi yakni kepala sekolah untuk melakukan pembinaan dan memantaukesesuaian antara perencanaan dan kegiatan yang telah dilaksanakan, dengan adanya kesesuaian tersebut maka hal tersebut memacu sekolah untuk melakukan perbaikan-perbaikan mutu di masa yang akan datang. Metode yang dilakukan pengawas sekolah adalah mewawancarai kepala sekolah terkait dengan delapan Standar Nasional Pendidikan yang telah tercapai, penelaahan dokumen administratif sekolah. Inovasinya dalam memimpin sekolah, dan capaian lima substansi manajemen pendidikan yang meliputi manajemen peserta didik, manajemen sumber daya manusia, manajemen kurikulum, manajemen sarana dan prasarana, dan manajemen keuangan sekolah sesuai dengan prinsip manajemen POAC (Planning, Organizing, Actuating, Controlling).

\section{Fungsi Supervisi Manajerial dalam rangka Implementasi MBS di SMP Negeri 1 Kanigoro}

Supervisi yang baik tidak akan terwujud tanpa adanya partisipasi warga sekolah untuk mengimplementasikan Manajemen Berbasis Sekolah yang baik. Sekolah yang baik sudah dipastikan menerapkan prinsip manajemen yang meliputi perencanaan, pengorganisasian, pelaksanaan, dan pengawasan. Kegiatan yang ditekankan di SMP Negeri 1 Kanigoro meliputi pembinaan dan pendampingan. Tujuan fungsi supervisi manajerial yang dimaksudkan adalah untuk melihat kesesuaian antara rencana dengan pelaksanaan, selain itu kegiatan supervisi yang dilakukan tim pengawas juga merupakan langkah asesment dari program-program sekolah mencakup standar proses, standar isi, standar kompetensi lulusan, standar pengelolaan, standar pembiayaan, standar tenaga pendidik dan tenaga kependidikan, standar sarana dan prasarana.

\section{Prosedur Supervisi Manajerial dalam rangka Implementasi MBS di SMP Negeri 1 Kanigoro}

Prosedur merupakan seperangkat mekanisme yang terkait dengan pelaksanaan suatu kegiatan. Prosedur tak lepas dari adanya perencanaan yang disusun sebelum prosedur itu dijalankan. Suatu supervisi 
melalui salah satu tahapan dalam manajemen yakni perencanaan, dengan adanya rencana kegiatan supervisi maka pelaksanaannya pun akan semakin baik. Pengawasan memiliki fungsi memantau dan mendampingi, jadi dengan adanya dua kegiatan penting tersebut maka data yang diperlukan pengawas pun akan diperoleh. Namun, untuk hal ini supervisi manajerial oleh pengawas sebagai alat pemantauan dari sembilan standar pendidikan.

Kegiatan pengawas dalam memantau manajerial sekolah adalah: Pertama, pengawas mendatangi sekolah binaan dan membawa instrumen untuk keperluan memperoleh data. Instrumen yang dibawa meliputi instrumen yang mencakup 8 Standar Nasional pendidikan. Kedua, pengawas akan meminta pihak sekolah untuk menunjukkan data dan dokumen yang terkait dengan penilaian, pengawas memperoleh data dengan teknik menelaah dokumen, dan melakukan wawancara kepada subyek sesuai dengan kepentingan penilaian dan monitoring. Supervisi manajerial terbagi menjadi tiga kegiatan yang diantaranya kegiatan pemantauan, pendampingan, dan penilaian. Ketika pengawas datang ke sekolah untuk memonitoring dan membawa instrumen maka kemudian meminta sekolah untuk menunjukkan dokumen yang perlu untuk dipantau serta melakukan wawancara, maka kegiatan tersebut adalah pemantauan. Namun berbeda halnya dengan pendampingan. Pertama, pengawas akan melakukan sosialisasi untuk masalah yang umum terjadi di sekolah, kedua, pengawas juga melakukan pendampingan penyusunan evaluasi diri sekolah dan rencana kegiatan anggaran sekolah dengan memecahkan masalah bersama.

\section{Peran Supervisor Manajerial dalam Implementasi MBS di SMP Negeri 1 Kanigoro}

Manajemen Berbasis Sekolah merupakan model pengelolaan sekolah dengan memberikan kewenangan yang lebih besar pada tingkat sekolah untuk mengelola sekolah sendiri secara langsung. Manajemen Berbasis Sekolah memiliki andil yang sangat besar terhadap kemajuan mutu sekolah di masa yang akan datang. Berbagai pihak dan stakeholder pun memiliki andil dalam memperoleh predikat sekolah berbasis manajemen, MBS sendiri mengacu pula pada Peraturan Pemerintah Nomor 19 Tahun 2005 tentang Standar Nasional Pendidikan yang diantaranya ada standar proses, standar kompetensi lulusan, standar isi, standar pendidik dan tenaga kependidikan, standar sarana dan prasarana, standar pembiayaan, standar pengelolaan, standar penilaian, serta standar internal sekolah yakni standar budaya dan lingkungan.

Supervisi merupakan salah satu kegiatan yang tidak akan terlepas dari pencapaian pendidikan di sekolah. Supervisi manajerial mutlak diperlukan dalam setiap pelaksanaan pekerjaan dalam mencapai tujuan dari setiap organisasi. Peran pengawas sendiri dalam implementasi Manajemen Berbasis Sekolah di SMP Negeri 1 Kanigoro memiliki andil sama seperti stakeholder lainnya. Bisa dinyatakan sekolah MBS jika seluruh komponen yang ada di sekolah itu benar-benar sudah bekerja sama membentuk sistem, saling terikat, saling terkait untuk melanjutkan visi misi yang sudah ditetapkan. Peran supervisor manajerial yang ditemukan dalam mengimplementasikan MBS di SMP Negeri 1 Kanigoro adalah: a) Memberikan arahan; b) Memantau jalannya proses pendidikan oleh KepalaSekolah; c) Pengawas mendukung dan memotivasi pihak sekolah untuk melakukan inovasi pelayanan mutu sekolah d) memberikan rekomendasi sesuai dengan permasalahan, akan tetapi pengambilan keputusan tetap ada pada wewenang Kepala Sekolah.

\section{PEMBAHASAN}

\section{Sasaran Pelaksanaan Supervisi Manajerial dalam Rangka Implementasi Manajemen Berbasis Sekolah di SMP Negeri 1 Kanigoro}

Manajemen Berbasis Sekolah tidak akan terwujud tanpa adanya partisipasi langsung dari warga sekolah, pendampingan dan supervisi manajerial yang dilaksanakan oleh pengawas sekolah. Begitu juga supervisi, supervisi juga memiliki sasaran tertentu agar manajemen di suatu sekolah menjadi lebih terarah dan terpantau sesuai dengan peraturan perundang-undangan manajemen pendidikan. Supervisi terbagi menjadi dua bidang yakni supervisi manajerial dan supervisi akademik. Supervisi manajerial adalah suatu upaya yang dilakukan pengawas untuk membina kepala sekolah khususnya, dan warga 
sekolah umumnya dalam pengelolaan sekolah. Sasaran supervisi manajerial adalah pengelolaan aspek pengelolaan dan administrasi sekolah yang berfungsi sebagai pendukung terlaksananya pembelajaran. Sedangkan supervisi akademik adalah suatu upaya yang dilakukan pengawas untuk memantau jalannya proses pembelajaran di suatu sekolah, dan menilai kinerja guru dalam melakukan kegiatan pengajaran.

Sasaran supervisi manajerial untuk meningkatkan manajemen sekolah melalui peningkatan kemampuan administratif tenaga kependidikan atau sumberdaya sekolah lainnya dalam melaksanakan tugas dan kewajiban yang mendukung terlaksananya proses pembelajaran dan peningkatan mutu di sekolah. Hal ini dilakukan setiap pengawas ketika melakukan supervisi manajerial pada sekolah binaannya.

Sasaran supervisi manajerial yang ditemukan sesuai dengan pendapat Sudrajat (2015: 21) bahwa "sasaran supervisi manajerial adalah membantu kepala sekolah dan staf sekolah lainnya dalam mengelola administrasi pendidikan. Hal ini berdasarkan dengan pernyataan pengawas SMP Negeri 1 Kanigoro bahwa sasaran supervisi Manajemen Berbasis Sekolah selain 9 Standar Nasional Pendidikan, sasaran supervisi adalah Kepala SMP Negeri 1 Kanigoro selaku manajer sekolah tersebut". Kepala sekolah akan diwawancarai tim pengawas terkait dengan 8 Standar Nasional Pendidikan dan 1 standar internal sekolah yang tercapai, inovasinya dalam memimpin sekolah dan capaian lima substansi manajemen pendidikan yang meliputi manajemen peserta didik, manajemen sumber daya manusia, manajemen kurikulum, manajemen sarana dan prasarana, dan manajemen keuangan sekolah sesuai dengan prinsip manajemen POAC (Planning, Organizing, Actuating, Controlling) melewati penanggung jawab 9 standar yang diserahi tanggung jawab oleh Kepala Sekolah. Selain itu Kepala Sekolah akan dinilai kinerjanya dengan dilaksanakannya Penilaian Kinerja Kepala Sekolah (PKKS) yang dilakukan setiap tahun dua kali, diawal tahun dan di akhir tahun. Penilaian ini dilakukan oleh pengawas bersama tim penilai yang beranggotakan 14 guru termasuk Kepala Tenaga Administrasi Sekolah dan guru SMP Negeri 1 Kanigoro, pengawas menilai kinerja Kepala Sekolah berlandaskan instrumen penilaian mengacu pada Peraturan Menteri Pendidikan Nasional Nomor 13 Tahun 2007 tentang Standar Kepala Sekolah yang meliputi enam kompetensi, yaitu kompetensi kepribadian dan sosial, kompetensi kepemimpinan pembelajaran, kompetensi pengembangan sekolah, kompetensi manajemen sumber daya, kompetensi kewirausahaan, dan kompetensi supervisi akademik.

Akan tetapi, ketercapaian ketaatan sesuai dengan standar manajerial sekolah perlu ditegakkan dan dilakukan oleh pengawas yang senantiasa melaksanakan fungsi pengawasan manajerial sekolah. Sudjana dkk. (2011: 21) menyatakan bahwa "Sasaran supervisi manajerial adalah membantu kepala sekolah dan staf sekolah lainnya dalam mengelola administrasi pendidikan, seperti administrasi kurikulum, administrasi keuangan, administrasi sarana prasarana dan perlengkapan, administrasi sumber daya manusia atau ketenagaan, administrasi kesiswaan, administrasi hubungan sekolah dan masyarakat, administrasi budaya lingkungan sekolah, serta aspek-aspek administrasi lainnya dalam upaya meningkatkan mutu pendidikan".

Sasaran supervisi manajerial tersebut terpenuhi oleh karena kompetensi pengawas manajerial yang tertera pada Permendiknas No. 12 Tahun 2017 tentang kompetensi supervisi manajerial poin ke lima yang berbunyi "Membina kepala sekolah dalam pengelolaan dan administrasi satuan pendidikan berdasarkan manajemen peningkatan mutu pendidikan di sekolah menengah yang sejenis". Hal inilah yang menentukan berhasil tidaknya pengawas dalam melakukan pembinaan kepala sekolah dan manajemen pendidikan sekolah yang relevan dengan peraturan tersebut, maka kompetensi tiap-tiap pengawas sangat berpengaruh dengan capaian mutu pendidikan di sekolah binaan.

Paradigma supervisi manajerial tidaklah sama dengan paradigma dimasa lampau. Dahulu, pengawasan dianggap sebagai kegiatan dimana pengawas akan memantau dan menyalahkan sekolah bila sekolah mengalami kemunduran atau hambatan pada bidang manajerialnya hal ini membuat pihak sekolah akan merasa tidak kompeten dalam melakukan pengelolaan. Seiring waktu, paradigma pengawasan berubah dan tidak lagi menjadi momok yang berarti pada pihak sekolah, jika dahulu sekolah akan menganggap pengawasan sebagai inspeksi maka kini sekolah akan menganggap pengawasan sebagai pendampingan dan pembinaan. 
Hasil temuan sementara mengenai fungsi supervisi manajerial adalah kegiatan yang dilaksanakan secara rutin tersebut memiliki fungsi pembinaan, dimana fungsi tersebut dipergunakan pengawas untuk melakukan koordinasi dengan kepala sekolah dan guru-guru yang bersangkutan lewat forum rapat. Forum tersebut membahas mengenai informasi-informasi terkini, kebijakan dinas, dan penguatan-penguatan materi. Pada dasarnya, supervisi manajerial adalah usaha pemberian bantuan yang diberikan oleh pengawas kepada pendidik dan tenaga kependidikan dalam rangka pembinaan, penilaian dan bimbingan mulai dari rencana program, proses, sampai dengan evaluasi, hasil dan laporan kegiatan. Maka, fungsi yang ditemukan sejauh ini adalah untuk melihat kesesuaian antara rencana, pelaksanaan, evaluasi dengan RTL (Rencana Tindak Lanjut) yang dilakukan sekolah. Secara umum, pengawas melihat program sekolah yang diajukan, pelaksanaan kegiatan, dokumen kegiatan seperti apa, dan evaluasi kegiatan. Setelah dokumen kegiatan selesai dievaluasi oleh pengawas, maka pengawas akan memberikan rekomendasi tindak lanjut. Rekomendasi ini digunakan sebagai langkah untuk mengembangkan manajerial sekolah agar kedepannya mampu memperbaiki diri.

Berdasarkan hal tersebut, supervisi bukan hanya sebagai alat ukur apakah program/rencana telah sesuai dengan pelaksanaannya. Akan tetapi, supervisi manajerial sebagai kegiatan pengawasan dibidang personil pelaksana dan manajemen sekolah yang menjalankan pengadministrasian sekolah dalam rangka meningkatkan kualitas proses pembelajaran. Hal inilah yang mendukung prinsip dan implementasi Manajemen Berbasis Sekolah di sekolah ini, yang kita tahu bahwa pelaksanaannya sejak tahun 1999 mengantarkan ribuan sekolah pada peningkatan mutu dan layanan manajemen pendidikan.

Dapat disimpulkan, bahwa fungsi supervisi manajerial tersebut sebagai upaya sekolah dalam meminimalisir kendala dalam pelaksanaan program kerja sekolah agar pelaksanaan kegiatan berjalan sebagai mana mestinya sebab supervisi manajerial dimaksudkan sebagai kegiatan pembinaan yang fokusnya aspek-aspek Manajemen Sekolah: men, money, materials. Fungsi tersebut tidak akan tercapai tanpa adanya kerjasama antara pengawas dan Kepala Sekolah selaku manajer pendidikan di SMP Negeri 1 Kanigoro, sebab fungsi tersebut merupakan tujuan pengawas melakukan supervisi manajerial sesuai prinsip Manajemen Berbasis Sekolah yang melibatkan partisipasi seluruh warga sekolah dan stakeholder. Diharapkan dengan adanya fungsi tersebut, semua pihak terkait mampu bekerjasama demi peningkatan layanan dan mutu yang berkualitas di bidang pendidikan dan Manajemen Berbasis Sekolah secara berkelanjutan.

Seperti dalam implementasi Manajemen Berbasis Sekolah di SMP Negeri Kanigoro melibatkan partisipasi warga sekolah dan masyarakat dalam menentukan ketercapaian standar mutu pendidikan. Maka, sasaran yang ada pun turut berpengaruh pada standarisasi Manajemen Berbasis Sekolah yang diterapkan SMP Negeri 1 Kanigoro sejak tahun 2005.

\section{Fungsi Supervisi Manajerial dalam rangka Implementasi Manajemen Berbasis Sekolah di SMP Negeri 1 Kanigoro}

Paradigma supervisi manajerial tidaklah sama dengan supervisi dimasa lampau. Dahulu, supervisi manajerial yang dilakukan oleh pengawas dianggap sebagai kegiatan dimana pengawas akan memantau dan menyalahkan sekolah bila sekolah mengalami kemunduran atau hambatan pada bidang manajerialnya hal ini membuat pihak sekolah akan merasa tidak kompeten dalam melakukan pengelolaan. Seiring waktu, paradigma supervisi manajerial berubah dan tidak lagi menjadi momok yang berarti pada pihak sekolah, jika dahulu sekolah akan menganggap supervisi manajerial sebagai inspeksi maka kini sekolah akan menganggap pengawasan sebagai pendampingan dan pembinaan. Menurut Joni, dkk (2016: 150) "fungsi utama supervisi bukan perbaikan saja, tapi dilaksanakan untuk mengkoordinasi, menstimulasi, dan mendorong kearah pertumbuhan dan pengembangan satuan pendidikan". Sementara hasil temuan mengenai fungsi supervisi manajerial adalah pembinaan yang bersifat memberikan arahan, mendukung program sekolah dan memberikan saran dari problema yang ditemukan ketika pihak sekolah menjalankan program yang dirancang. Fungsi tersebut dipergunakan pengawas untuk melakukan koordinasi dengan kepala sekolah dan guru-guru yang bersangkutan lewat forum rapat. 
Pada dasarnya, supervisi manajerial adalah usaha pemberian bantuan yang diberikan oleh pengawas kepada pendidik dan tenaga kependidikan dalam rangka pembinaan, penilaian dan bimbingan mulai dari rencana program, proses, sampai dengan evaluasi, hasil dan laporan kegiatan. Fungsi kedua dari pelaksanaan supervisi manajerial oleh pengawas adalah untuk melihat kesesuaian antara rencana, pelaksanaan, evaluasi dengan RTL (Rencana Tindak Lanjut) yang dilakukan Kepala Sekolah untuk melaksanakan program sekolah. Secara umum, pengawas melihat program sekolah yang diajukan, pelaksanaan kegiatan, dokumen kegiatan, dan melakukan evaluasi kegiatan. Setelah dokumen kegiatan selesai dievaluasi oleh pengawas, maka pengawas akan memberikan rekomendasi tindak lanjut. Rekomendasi ini digunakan sebagai langkah untuk mengembangkan manajerial sekolah agar kedepannya mampu memperbaiki diri.

\section{Prosedur Pelaksanaan Supervisi Manajerial dalam rangka Implementasi Manajemen Berbasis Sekolah di SMP Negeri 1 Kanigoro}

Prosedur merupakan langkah-langkah kegiatan secara teknis dan saling terkait. Prosedur seringkali dilaksanakan oleh pengawas manajerial sebagai langkah awal dalam melakukan pengawasan sekolah. Sebab, supervisi manajerial dimaksudkan kegiatan pengawasan yang fokusnya aspek-aspek yang berkaitan dengan manajemen sekolah meliputi delapan Standar Nasional Pendidikan, fungsi manajemen POAC (Planning, Organizing, Actuating, Controlling), serta 3M (Men, Money, Materials).

Berdasarkan temuan penelitian dapat diketahui bahwa, Pertama pengawas datang ke sekolah dengan membawa instrumen untuk keperluan memperoleh data. Kedua, pengawas akan meminta pihak sekolah untuk menunjukkan data dan dokumen yang terkait dengan penilaian, misalnya penilaian atau monitoring standar proses pembelajaran, pada awal semester tim petugas monitoring akan menelaah dokumen program sekolah yang telah diajukan kepada pengawas, jika dokumen tersebut disetujui maka pengawas akan melakukan validasi menggunakan aplikasi. Selain itu, untuk memperoleh data pengawas melakukan wawancara kepada subyek sesuai dengan kepentingan penilaian dan monitoring.

Supervisi manajerial yang dilakukan oleh pengawas terbagi menjadi tiga kegiatan yang diantaranya kegiatan pemantauan, pendampingan, dan penilaian. Ketika pengawas datang ke sekolah untuk memonitoring dan membawa instrumen maka kemudian meminta sekolah untuk menunjukkan dokumen yang perlu untuk dipantau serta melakukan wawancara, maka kegiatan tersebut adalah pemantauan. Namun berbeda halnya dengan pendampingan. Pertama, pengawas akan melakukan sosialisasi untuk masalah yang umum terjadi di sekolah, kedua, pengawas juga melakukan pendampingan penyusunan evaluasi diri sekolah dan rencana kegiatan anggaran sekolah dengan memecahkan masalah bersama.

Ketiga, kegiatan penilaian. Kegiatan penilaian terbagi menjadi dua jenis yakni Penilaian Kinerja Kepala Sekolah (PKKS) dan Penilaian Kinerja Guru (PKG). Pertama, kegiatan PKKS. Pengawas akan melakukan pengkajian dokumen lalu mewawancarai kepala sekolah sesuai data yang diperlukan. Kedua, kegiatan PKG. Mula-mula pengawas akan melakukan wawancara, melakukan observasi ke kelas, dan melakukan pengamatan selama 80 menit. Disamping dikaji dokumen yang menyertai tugastugasnya sebagai guru, kegiatan yang menjadi fokus utama adalah menilai kemampuan mengajar guru dan menguji para siswa tentang penguasaan pelajaran yang menjadi tanggung jawab guru tersebut.

Adanya kegiatan tersebut membantu pengawas memantau dan mengontrol kinerja Kepala Sekolah, guru, staf, dan tenaga kependidikan lainnya sesuai dengan prinsip Manajemen Berbasis Sekolah yang baik. Pelaksanaan prinsip Manajemen Berbasis Sekolah ini disusun oleh Kepala Sekolah, yakni terbuka, transparan, akuntabel dan toleransi. Prinsip ini merupakan langkah tindak lanjut dari Kepala SMPN 1 Kanigoro terdahulu yang mengantarkan sekolah ini menjadi sekolah Adiwiyata Nasional dan Sekolah Model.

Setelah kegiatan dirasa cukup oleh pengawas, maka pengawas akan memperoleh data dan melakukan dokumentasi untuk keperluan evaluasi dan monitoring, dengan hal tersebut maka akan diperoleh rekomendasi program kegiatan di masa yang akan datang yang menentukan kemajuan tingkat kualitas pendidikan di SMP Negeri 1 Kanigoro. 


\section{Peran Supervisor Manajerial dalam rangka Implementasi Manajemen Berbasis Sekolah di SMP Negeri 1 Kanigoro Blitar}

Peran merupakan aspek dinamis kedudukan (status), apabila seseorang melaksanakan hak dan kewajibannya sesuai dengan kedudukannya. Jika peran supervisi manajerial dapat di artikan sebagai aktivitas campur tangan yang melibatkan pengawas apabila melaksanakan hak dan kewajibannya sesuai dengan kedudukannya dalam mengelola pendidikan di sekolah.

Peran pengawas dalam implementasi Manajemen Berbasis Sekolah penting adanya, karena setiap rekomendasi dari sebuah permasalahan yang dihadapi sekolah menjadikan sekolah memiliki inovasi untuk meningkatkan mutunya. Pengawas umumnya membina dan mendampingi ketika sekolah memiliki kendala di bidang tertentu, maka dari itu peran pengawas sangatlah dibutuhkan untuk kepentingan mutu sekolah.

Dilihat dari pernyataan diatas, peran yang nampak bukan hanya sebagai konsultan dan advicer, melainkan juga sebagai motivator ketika pihak sekolah belum mampu memenuhi standar nasional pendidikan pada sekolah nya. Sekolah yang baik harus dapat menerapkan dan memperoleh nilai yang baik di bidang monitoring serta memenuhi kategori instrumen penilaian dari pengawas yang mencakup: a) standar proses, b) standar isi, c) standar pengelolaan, d) standar sarana dan prasarana, e) standar pembiayaan, f) standar pendidik dan kependidikan, g) standar kompetensi lulusan dan h) standar penilaian pendidikan. Adanya hal tersebut dapat diketahui bahwa peran pengawas sangat sesuai dengan tata kelola manajemen pendidikan di sekolah secara baik menurut perundang-undangan. Pengawas akan mendukung segala kegiatan yang bertujuan untuk kemajuan pendidikan, pembelajaran dan mutu pendidikan. Jika dilihat dalam temuan penelitian, prinsip Manajemen Berbasis Sekolah yang diberlakukan oleh Kepala SMP Negeri 1 Kanigoro adalah keterbukaan (transparansi), kemudian ada rasa saling tanggungjawab sesuai dengan tupoksinya (akuntabilitas), Maka, peran pengawas sangat diperlukan agar prinsip Manajemen Berbasis Sekolah tetap diterapkan dan dipertahankan di sekolah. Mengingat pemantauan yang dilakukan pengawas memegang peran penting untuk mengendalikan berbagai komponen sumber daya pendidikan agar berjalan sebagaimana tujuan yang hendak dicapai.

\section{KESIMPULAN DAN SARAN}

\section{Kesimpulan}

Sasaran supervisi manajerial dimaksudkan menjadi poin penting atas ketercapaian pelaksanaan supervisi manajerial di suatu sekolah berjalan dengan harapan yang semestinya. Pengawas dalam melakukan supervisi manajerial tentunya perlu memperhatikan beberapa kompetensi kepala sekolah dalam mengelola manajerial. Supervisi manajerial oleh pengawas sebagai alat ukur terlaksananya decision making yang dilakukan oleh kepala sekolah dalam melaksanakan pengelolaan sekolah.

Prosedur supervisi manajerial meliputi pemantauan dengan mengisi instrumen dari pengawas dan penelaahan dokumen, pendampingan yang dilakukan oleh pengawas untuk peningkatan kinerja pengelolaan manajerial sekolah yang memiliki aspek Manajemen Sumber Daya Manusia, Manajemen Peserta Didik, Manajemen, Perpustakaan, Manajemen Sarana dan Prasarana, Manajemen Keuangan, Manajemen Layanan Khusus.

Peran pengawas dalam melakukan supervisi manajerial berbasis MBS sangat berpengaruh, tanpa adanya supervisi manajerial di sekolah yang dilakukan pengawas, maka sekolah tidak akan mampu mengembangkan sekolahnya hingga memperoleh predikat Adiwiyata Nasional.

\section{Saran}

Saran yang dapat diberikan adalah: 1) Bagi Pengawas SMP Negeri 1 Kanigoro Blitar diharapkan dapat memaksimalkan perannya. Hal ini dapat dilakukan peningkatan profesionalisme pengawas dengan menyelenggarakan atau mengikuti pelatihan profesionalisme kinerja bagi pengawas muda, madya, dan utama di seluruh satuan pendidikan. Agar melakukan kegiatan supervisi manajerial 
kepada sekolah binaannya secara merata tidak hanya di pusat pemerintahan, tetapi juga di sekolah yang daerahnya jauh dari kawasan pusat pemerintahan; 2) Bagi Kepala SMP Negeri 1 Kanigoro Blitar hendaknya meningkatkan kerjasama kepada masyarakat sekitar, alumni dan pemimpin daerah demi tercapainya tujuan pendidikan. Alangkah lebih baik jika manajemen layanan khusus siswa meningkat seiring waktu berjalan, hal ini dapat dilakukan dengan mengembangkan lahan parkir, kantin (cafetaria sekolah), transportasi sekolah, gedung olahraga (perlengkapannya), agar pelaksanaan pembelajaran dan pemenuhan pelayanan siswa tetap berjalan dengan baik; 3)Bagi guru atau tenaga kependidikan yang ada di SMP Negeri 1 Kanigoro diharapkan lebih meningkatakan kualitas sumber pembelajaran yang bermutu untuk siswa/siswi di SMP Negeri 1 Kanigoro, hal ini dapat dilakukan dengan mengikuti pendampingan kurikulum KTSP atau K13 yang diselenggarakan oleh pengawas Dinas Pendidikan, serta meningkatkan kualitas belajar anak didik di SMP Negeri 1 Kanigoro dan mencapai standar kompetensi lulusan yang ditetapkan pemerintah; 4) Bagi Jurusan Administrasi Pendidikan diharapkan untuk lebih mengoperasionalkan supervisi manajerial di jurusan administrasi pendidikan serta menambah kajian tentang supervisi manajerial dalam rangka implementasi Manajemen Berbasis Sekolah (MBS); 5) Bagi Peneliti Lain diharapkan dapat menjadi masukan dalam mengkaji lebih lanjut terkait tema ini. Misalnya dalam upaya SMP Negeri 1 Kanigoro mempertahankan mutu sekolah dan mengembangkan nilai budaya dan lingkungannya agar predikat adiwiyata lebih berkembang dari saat ini.

\section{DAFTAR RUJUKAN}

Joni, S. Djailani, I. \& Sakdiah. 2016. Pelaksanaan Supervisi Manajerial Pengawas Sekolah Pada Sekolah Menengah Atas Swasta di Kota Banda Aceh. Jurnal Administrasi Pendidikan Pascasarjana Universitas Syiah Kuala ISSN 2302-0156. Volume 4, No. 1, Februari 2016. Magister Administrasi Pendidikan Program Pascasarjana Universitas Syiah Kuala Banda Aceh.

Satori, Djam'an. 2016. Pengawasan dan Penjaminan Mutu Pendidikan. Alfabeta: Bandung

Sudjana dkk, Nana. 2011. Buku Kerja Pengawas Sekolah. Jakarta: Kemendiknas.

Sudrajat, Akhmad. 2008. "Tugas Pokok dan Fungsi Pengawas Sekolah.” Dalam http://akhmadsudrajat.wordpress. com/2008/04/08/tugas-pokok-fungsi-hak-dan-wewenang-pengawas-sekolahsatuan-pendidikan/. 